\title{
Article \\ A Combined Strategy to Improve the Performance of Dental Alloys Using a New CoCrNbMoZr Alloy with Mn and Si Coated via an Anodic Oxidation Procedure
}

\author{
Florentina Gina Ionascu ${ }^{1}$, Mariana Prodana ${ }^{1}$, Florentina Golgovici ${ }^{1, *(D)}$ and Ioana Demetrescu ${ }^{1,2}$ (D) \\ 1 Department of General Chemistry, Faculty of Applied Chemistry and Materials Science, \\ University Politehnica of Bucharest, Spl. Independentei 313, 060042 Bucharest, Romania; \\ flori.ionascu@yahoo.com (F.G.I.); mariana.prodana@upb.ro (M.P.); ioana.demetrescu@upb.ro or \\ ioana_demetrescu@yahoo.com or I_demetrescu@chim.upb.ro (I.D.) \\ 2 Academy of Romanian Scientists, 3 Ilfov, 050044 Bucharest, Romania \\ * Correspondence: florentina.golgovici@upb.ro; Tel.: +40-214-023-930
}

check for

updates

Citation: Ionascu, F.G.; Prodana, M.; Golgovici, F.; Demetrescu, I. A Combined Strategy to Improve the Performance of Dental Alloys Using a New CoCrNbMoZr Alloy with Mn and Si Coated via an Anodic Oxidation Procedure. Metals 2021, 11, 1017. https://doi.org/10.3390/ met11071017

Academic Editor: Han-Cheol Choe

Received: 25 May 2021

Accepted: 22 June 2021

Published: 24 June 2021

Publisher's Note: MDPI stays neutral with regard to jurisdictional claims in published maps and institutional affiliations.

Copyright: (c) 2021 by the authors. Licensee MDPI, Basel, Switzerland. This article is an open access article distributed under the terms and conditions of the Creative Commons Attribution (CC BY) license (https:/ / creativecommons.org/licenses/by/ $4.0 /)$.

\begin{abstract}
The aim of the paper is based on a combined approach to improve dental alloy performance using a new $\mathrm{Ni}$-free $\mathrm{Co}-\mathrm{Cr}$ composition with $\mathrm{Mo}, \mathrm{Nb}$ and $\mathrm{Zr}$ and coated with an anodic oxidation film. The coated and uncoated samples were surface characterized by performing SEM (scanning electronic microscopy), XRD (X-rays diffraction) contact angle measurements and corrosion studies with open circuit potential, potentiodynamic polarization and EIS (impedance electrochemical spectroscopy) procedures. The SEM equipment with an EDX (Energy-dispersive X-ray spectroscopy) module indicated the sample morphology and the XRD investigations established the formation of the oxides. The electrochemical procedures were performed in Ericsson artificial saliva for coated samples in various conditions. Based on all the experiments, including the decrease in the hydrophobic character of the uncoated samples and the decrease in the hydrophilic values of the anodized alloys, the improved performance of the coated samples was established as a conclusion.
\end{abstract}

Keywords: CoCrMoNbZr alloy; SEM; XRD; contact angle; tafel plots; EIS

\section{Introduction}

A new $\mathrm{Co}-\mathrm{Cr}$ alloy with $\mathrm{Nb}$ and $\mathrm{Zr}$ was proposed as material for dentistry in the context of new strategies for such alloys and the technological revolution of the restorative dentistry sector during the 21st century $[1,2]$. In relation to this, in the last decade, the dental restorative sector has witnessed the appearance of new technologies in both the digital and manufacturing industries to overcome the drawbacks of conventional manufacturing processes, such as the wax-lost casting method. The influence of the microstructure and topography on the mechanical properties of $\mathrm{Co}-\mathrm{Cr}$ dental-prosthesis restorations made by computer-aided design and milling subtractive systems (CADCAM) milling system and laser sintering system manufacturing has been investigated, and it has been suggested that for an identical chemical composition, the differences in the mechanical properties mainly depend on the factors related to the variations in the microstructure and defects connected to the manufacturing methods [3]. In addition, there are meaningful data on the corrosion and toxicity of $\mathrm{Co}-\mathrm{Cr}$ alloys for their use in restorative works as dental prostheses [4,5]. The temperature effect on corrosion [6] and toxicological studies following Co and Cr exposure in the oral cavity are more difficult to conduct because there are many different situations that lead to the release of metal ions and wear particles. Furthermore, the links between exposure and the appearance of local or systemic toxicity are not straightforward [7]. Without a history of the use of the Co-Cr alloy in dental works, it worth mentioning in short some of their merits and demerits to understand their success and, simultaneously, the necessity of developing new strategies for their use [8-10]. The main strategies have introduced new extended procedures for Co-Cr surface modifications [11-16] or have 
changed their composition [17-19]. The use of CoCrMo dental alloys on a mass scale has led sometimes to certain pigment metallic lesions that are even more aggressive due to their ion release $[20,21]$. The success of such strategies is mainly related to the enhanced mechanical properties of this alloy such as hardness and wear, and a better antibacterial and corrosion resistance, together with their good price value compared to other dental alloys. Since 2017, the European Union (EU) regulatory framework for $\mathrm{Co}-\mathrm{Cr}$ alloys has undergone profound changes. A new EU Medical Devices Regulation [22] (MDR) (2017/745)15 will be applied in May 2021 which considers the Co metal as a new, carcinogenic, mutagenic, and toxic to reproduction (CMR) substance. On 18 February 2020, the 14th Adaptation to Technical Progress (ATP14) to the Classification, Labelling and Packaging (CLP) regulation was published, including the harmonised classification for the Co metal as a CMR 1B substance [23]. In this context, the use of Co might be forbidden if the medical devices are invasive and if they include more than $0.1 \%(\mathrm{~m} / \mathrm{m})$ Co. Of course, this is a future trend, and it is orientated towards the elimination of $\mathrm{Co}-\mathrm{Cr}$ from dental applications due to their toxicity, as mentioned in the EU regulation, but the tendency to eliminate toxic elements from dentistry has a relatively slow rate depending on many economic reasons. The $\mathrm{Co}-\mathrm{Cr}$ alloys are still being investigated using novel manufacturing technologies due to their remarkable mechanical properties, corrosion resistance and price value compared to other alloys for biomedical applications [24].

This manuscript is an example of combining both strategies to limit the risks of exploiting a new biomedical alloy based on $\mathrm{Co}-\mathrm{Cr}$ with a new composition $[25,26]$ and an anodic oxidation procedure. The native passive film existing on the new $\mathrm{CoCrNbMoZr}$ alloy surface is thicker and more compact than that on the commercial Heraenium CE alloy surface because it contains both chromium and molybdenum oxides, and, in addition, niobium and zirconium oxides that have been confirmed by XPS analysis [25]. The quantity of the ions released in solution was significantly lower for the new alloy, showing its improved corrosion resistance. A stability comparison was performed in Carter-Brugirard [25] saliva revealing a much lower value for corrosion current density and rate and a higher value of the polarization resistance for the new alloy than that for the commercial CoCrMo type Heraenium $\mathrm{CE}$. The cell viability on the $\mathrm{CoCrNbMoZr}$ alloy was significantly higher in comparison with that on Heraenium CE. The strategy of the new investigation in this present paper and its novel character consists of providing a new composition as well as a new coating simultaneously for an improved performance of the alloy. Considering that, to our best knowledge, this alloy with a new composition has had few investigations into its properties $[18,26]$, this approach highlights new and interesting results for dental applications. The alloy is Ni-free, and the characterization presented includes the determination of its surface properties using methods such as SEM (scanning electronic microscopy), X-rays diffraction (XRD) contact angle and electrochemical behavior in Ericsson saliva for coated and uncoated alloy samples.

\section{Materials and Methods}

\subsection{Materials}

A new CoCrNbMoZr alloy obtained by vacuum melting using the semi-levitation method, as presented in previous papers $[18,25,26]$ was used in this paper. The chemical composition of this alloy has been established from EDX analysis performed with an energy dispersive spectra detector (EDS), attached to Hitachi SU 8230 Scanning Electron Microscope (Hitachi, Tokyo, Japan) and is presented in Table 1.

Table 1. Composition of the CoCrNbMoZr alloy.

\begin{tabular}{ccccccc}
\hline \multicolumn{7}{c}{ Alloying Elements, [wt. \%] } \\
\hline Co & $\mathrm{Cr}$ & $\mathrm{Nb}$ & $\mathrm{Mo}$ & $\mathrm{Zr}$ & $\mathrm{Mn}$ & $\mathrm{Si}$ \\
\hline $60 \pm 1.4$ & $26.5 \pm 0.9$ & $6 \pm 0.5$ & $4.5 \pm 0.3$ & $0.8 \pm 0.2$ & $0.8 \pm 0.2$ & $1 \pm 0.2$ \\
\hline
\end{tabular}


The samples used had a disc shape with a diameter of $10 \mathrm{~mm}$ and a thickness of $2 \mathrm{~mm}$. Before the electrochemical surface modification, the studied alloy was mechanically ground with abrasive paper (from 600 to 2000 grits) and ultrasonically cleaned in acetone for $10 \mathrm{~min}$ to remove impurities on the surface due to polishing and drying at room temperature. The surface exposed to electrochemical testing was always $1 \mathrm{~cm}^{2}$.

\subsection{Surface Modification}

Anodic oxidation of the $\mathrm{CoCrNbMoZr}$ alloy was conducted in a traditional threeelectrode cell composed of a $\mathrm{Ag} / \mathrm{AgCl}$ reference electrode, a counter electrode consisting of a platinum mesh and the working electrode-the studied alloy. The electrolyte used was $0.5 \mathrm{M} \mathrm{H}_{2} \mathrm{SO}_{4}$ at room temperature. Three replicates were conducted to ensure the reproducibility of each test. All electrochemical tests were performed using an AutoLab PGSTAT 12 EcoChemie potentiostat/galvanostat (Radiometer Analytical SAS, Lyon, France).

\subsection{Morphological and Structural Surface Analysis}

For the morphological characterization, scanning electron microscopy (SEM) measurements were taken by a Hitachi SU 8230 Scanning Electron Microscope (Hitachi, Tokyo, Japan) with an energy dispersive spectra detector (EDS) which was used to perform sample analysis. A $10 \mathrm{kV}$ voltage was used for analysis.

XRD patterns were obtained using a SmartLab X Ray Diffractometer (Rigaku Corporation, Tokyo, Japan) using $\mathrm{CuK} \alpha$ radiation $(\lambda=1.5406 \AA)$ and operating at room temperature. $X$-ray diffraction measurements of all the samples were carried out in the $20-100^{\circ}$ range. The identification of the phase was made by referring to the International Center for Diffraction Data-ICDD (PDF-2) database.

To estimate the hydrophilicity/hydrophobicity of the samples, the static contact angles were measured using a Contact Meter CAM 100 equipment (KSV Instruments Ltd, Helsinki, Finland). The presented results are the average of five measurements on five different areas of the same specimen. For contact angle measurements, values smaller than $30^{\circ}$ indicate a good premise for bioadhesion and a positive cell response $[27,28]$.

\subsection{Bio-Corrosion Tests}

The electrochemical characterization of the anodized samples was carried out in the same electrochemical cell as the anodisation. The biological environment was simulated by using Ericsson artificial saliva with the following composition (g/L): NaCl-0.584, $\mathrm{Na}_{2} \mathrm{HPO}_{4}-0.34, \mathrm{KH}_{2} \mathrm{PO}_{4}-0.34, \mathrm{KHCO}_{3}-1.5, \mathrm{MgCl}_{2}-0.014, \mathrm{CaCl}_{2}-0.166$, citric acid-0.029 $(\mathrm{pH}=6.7)$ [29]. A volume of $25 \mathrm{~mL}$ of the electrolyte was used each time. The temperature at which all the electrochemical characterizations were made was $37 \pm 0.5^{\circ} \mathrm{C}$. After an open circuit potential (OCP) test for $10 \mathrm{~min}$, electrochemical impedance spectroscopy (EIS) and the potentiodynamic polarization were performed, respectively.

The impedance spectra were obtained at open circuit potential with a scan frequency range from $10^{5} \mathrm{~Hz}$ to $10^{-2} \mathrm{~Hz}$ and an ac amplitude of $10 \mathrm{mV}$. The impedances were represented as Nyquist and Bode spectra. To obtain quantitative data, the experimental EIS results were simulated with equivalent electrical circuits as appropriate models using ZView 2.90c software (Scribner Associates Inc., Southern Pines, NC, USA).

In order to allow the corrosion process to proceed, potentiodynamic polarization tests were performed starting from the cathodic region, with a very low speed of $2 \mathrm{mV} / \mathrm{s}$ [30].

The potential of the working electrode was always measured against the $\mathrm{Ag} / \mathrm{AgCl}$ electrode and plotted in relation to the current in the external circuit to obtain the anodic and cathodic polarization curves. Three replicates were conducted to ensure the reproducibility of each test. 


\section{Results and Discussion}

\subsection{CoCrNbMoZr Alloy Anodisation}

To determine the potentials to be applied for the anodization, a potentiodynamic polarization curve of the alloy in $0.5 \mathrm{M}$ sulphuric acid solution was recorded, using a sweep rate of $2 \mathrm{mV} / \mathrm{s}$ of the potential.

As can be seen from Figure 1, a passive film was formed on the surface of the alloy, which led to a decrease in the value of the corrosion current density. The current density had a peak at $0.2 \mathrm{~V}$, corresponding to the active state dissolution of elements. Sweeping the potential towards more electropositive values, a decrease in the current density values can be observed. Starting with approximately $+0.5 \mathrm{~V}$, which represents the passivation potential, the current density value remained relatively constant until $1 \mathrm{~V}$. Because the air-formed passive oxide film was partially removed once, it can be said that the passive oxide film was reformed in $\mathrm{H}_{2} \mathrm{SO}_{4}$. The current density drastically increased beyond $1 \mathrm{~V}$, indicating that this is the passivation-depassivation potential and the start of the transpassive state. The protective layer began to form at about $0.5 \mathrm{~V}$. This layer started to break at about $1.06 \mathrm{~V}$.

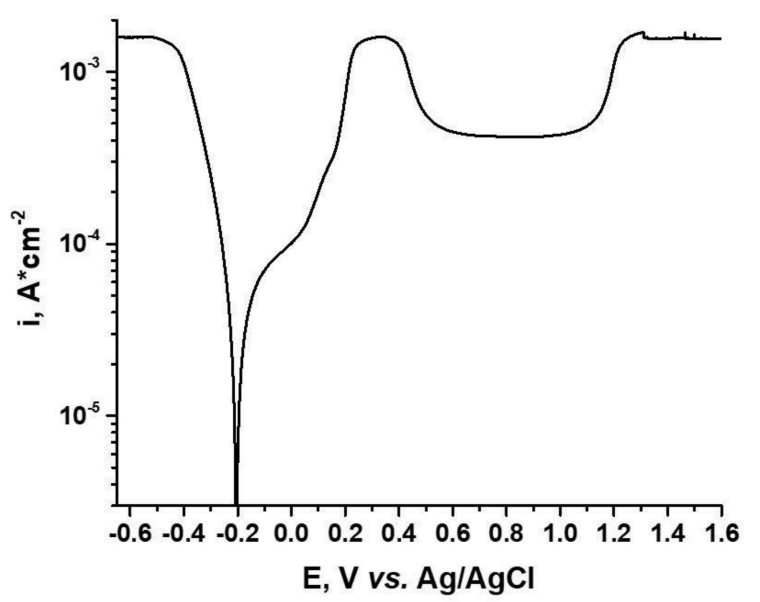

Figure 1. Potentiodynamic polarization curve for the new $\mathrm{CoCrNbMoZr}$ alloy in $0.5 \mathrm{M} \mathrm{H}_{2} \mathrm{SO}_{4}$.

Following the findings, the anodic polarization of the alloy was achieved, with chosen potentials of $1 \mathrm{~V}, 1.05 \mathrm{~V}$ and $1.1 \mathrm{~V}$, respectively. The potentials were applied for $3 \mathrm{~h}$ using $0.5 \mathrm{M} \mathrm{H}_{2} \mathrm{SO}_{4}$ as electrolyte.

The following notations will be used:

S1 samples for the non-anodized alloy;

$\mathrm{S} 2$ anodized alloy at a potential of $1 \mathrm{~V}$ for $3 \mathrm{~h}$;

$\mathrm{S} 3$ anodized alloy at a potential of $1.05 \mathrm{~V}$ for $3 \mathrm{~h}$;

$\mathrm{S} 4$ anodized alloy at a potential of $1.1 \mathrm{~V}$ for $3 \mathrm{~h}$.

\subsection{Morphological and Structural Characterisation}

\subsubsection{Scanning Electron Microscopy (SEM) Measurements}

In order to obtain information about the morphology of the control sample and the anodized samples under potentiostatic control and how they changed as the applied voltage increased, SEM microscopy was applied. Five measurements were performed each time. Figure 2 presents the morphology for sample one, the control sample. The morphology revealed a relatively clean surface for $\mathrm{S} 1$ and the presence of two-component phases. The main phase contains dendritic microstructures with the distance between the lines of inclusions of approximatively $10 \mu \mathrm{m}[18,31]$. 


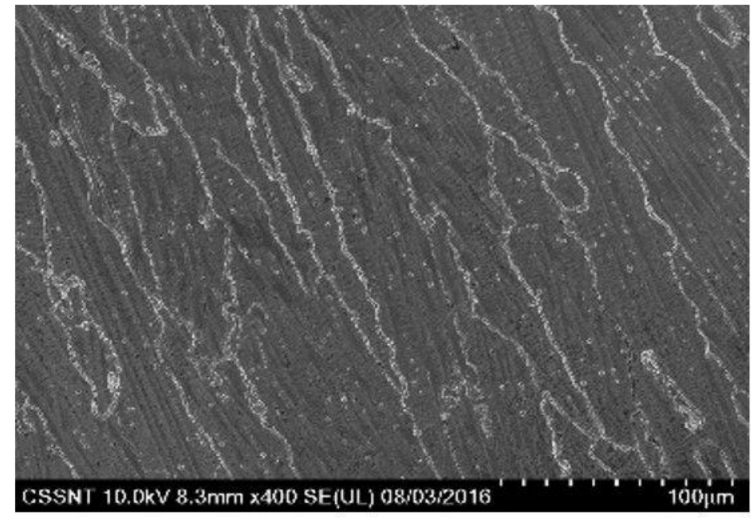

a

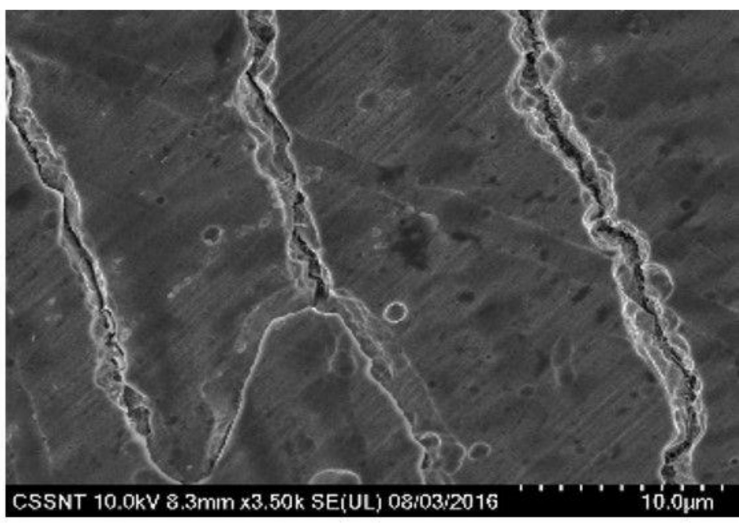

b

Figure 2. The surface morphology for S1 at two magnifications: (a) $400 \times$ magnification; (b) $3.5 \mathrm{k} \times$.

Before the oxidation procedure, the new alloy (S1) had a native oxide layer that was approximately $6.5-8 \mathrm{~nm}$ thick that can confer protection to the substrate [25]. However, during the oxidation procedure, with an increased polarization resistance, such values decreased before increasing simultaneously with the passivation-depassivation process.

Figure 3 presents the examples of the SEM micrographs of the electrochemically synthesized layers on the CoCrNbMoZr investigated metallic substrates.

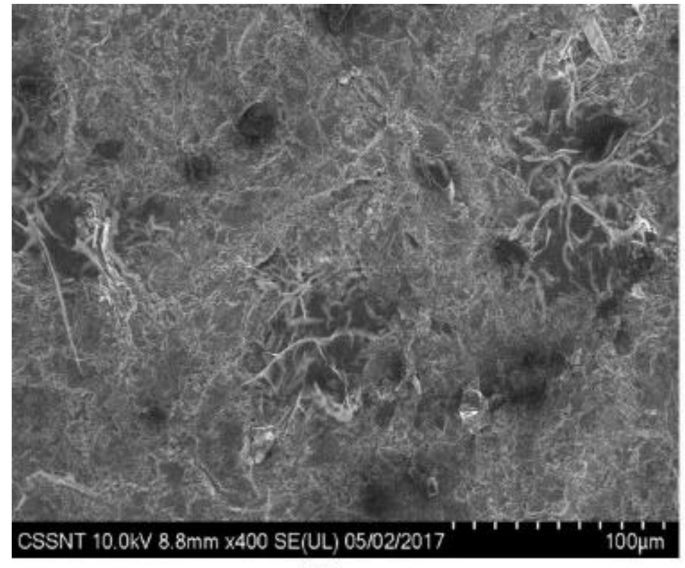

a

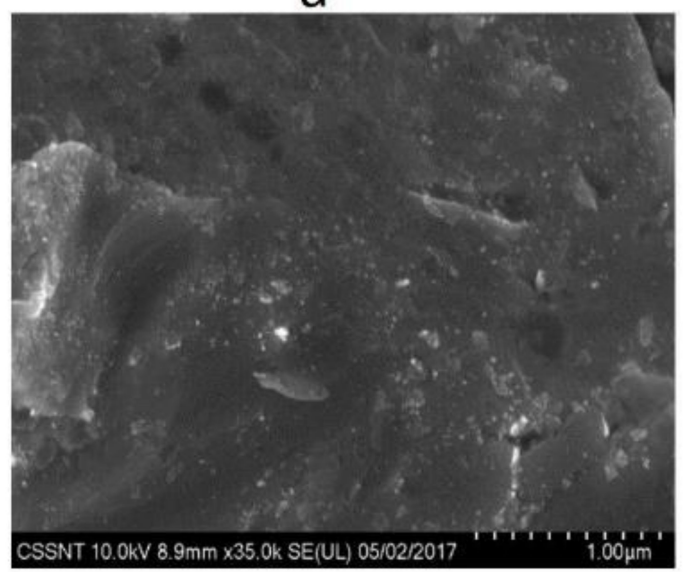

C

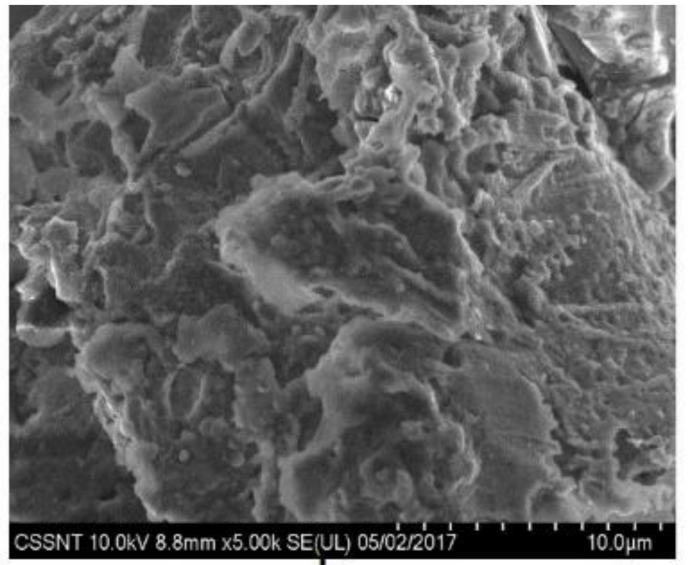

b

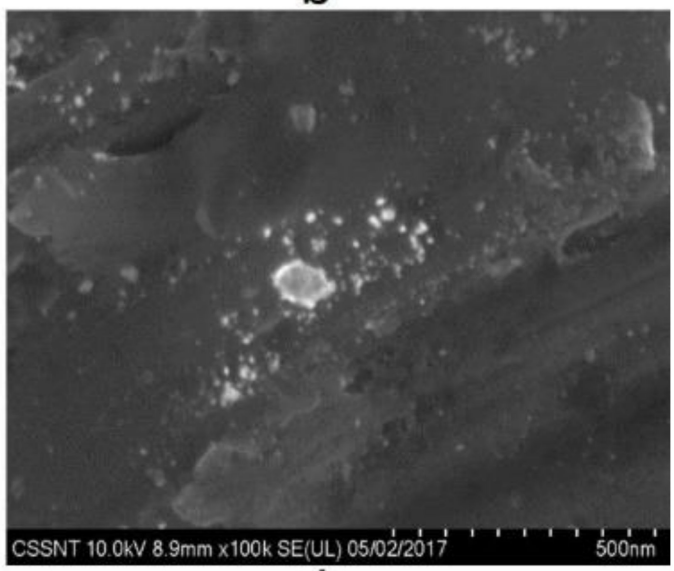

d

Figure 3. The surface morphology for S2 using different magnifications: (a) $400 \times$; (b) $5 \mathrm{k} \times$; (c) $35 \mathrm{k} \times$; (d) $100 \mathrm{k} \times$. 
For sample two, defined as $\mathrm{Co}-\mathrm{Cr}$ obtained at $+1.00 \mathrm{~V}$, we can observe in Figure 3 the morphology of the surface.

A compact layer appeared on the surface of the first sample. The entire surface of the sample is covered with layers of oxides with different morphologies. The porous structures can be seen in the SEM images.

For sample three, defined as $\mathrm{CoCr}$ obtained at $+1.05 \mathrm{~V}$, we can observe in Figure 4 that on the surface of the sample an oxide layer appeared that is relatively continuous and compact with different thicknesses.

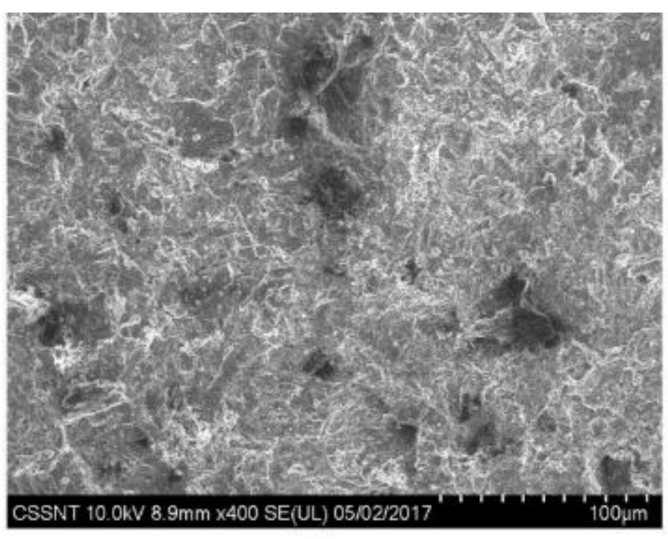

a

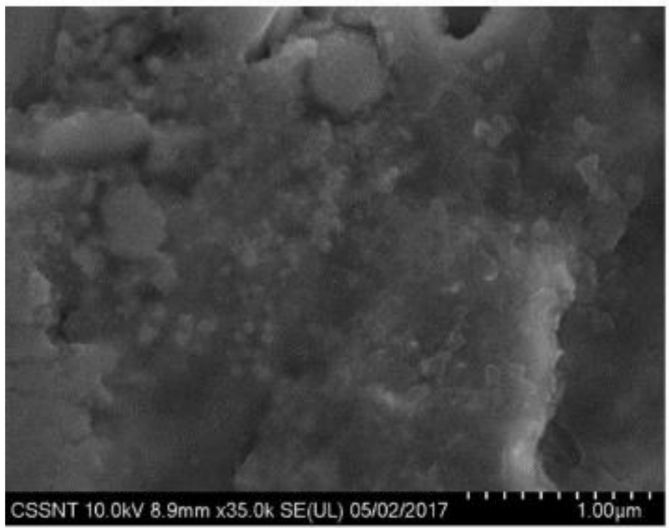

C

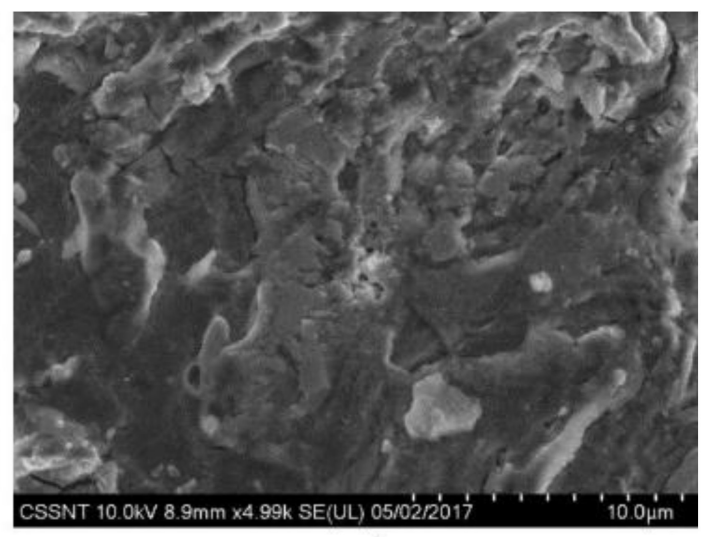

b

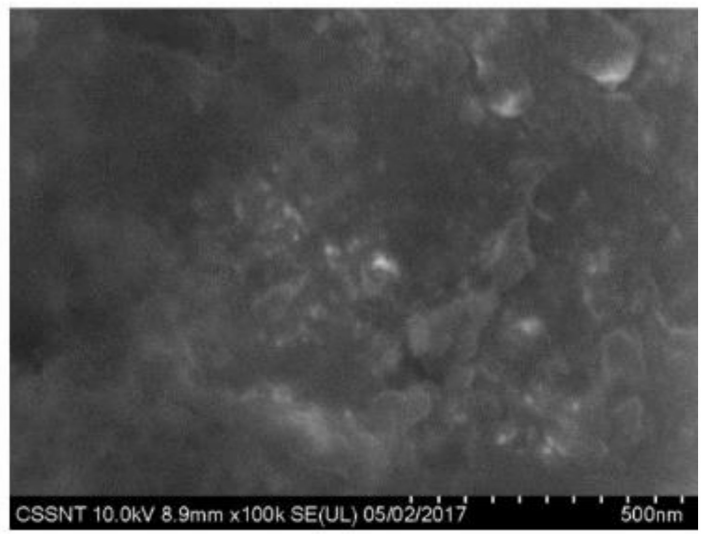

d

Figure 4. The surface morphology for S3 using different magnifications: (a) $400 \times$; (b) $5 \mathrm{k} \times$; (c) $35 \mathrm{k} \times$; (d) $100 \mathrm{k} \times$.

For sample four, defined as CoCr obtained at $+1.10 \mathrm{~V}$, the morphology of the surface is shown in Figure 5.

It can be seen that the surface of sample four is completely covered with oxide layers but, from place to place, the oxide layers show some cracks. At larger magnifications, we can see that those significant cracks of approximately $1 \mu \mathrm{m}$ in size easily detached from the surface of the $\mathrm{Co}-\mathrm{Cr}$ alloy treated at $1.1 \mathrm{~V}$.

As for the non-anodized sample, from the EDX analysis we obtained the composition of the surfaces of the three anodized samples at different potentials (Table 2). We observed that the oxygen peak appeared in the four spectra, but peaks for $\mathrm{Co}, \mathrm{Mo}, \mathrm{Cr}, \mathrm{Si}, \mathrm{Zr}, \mathrm{Nb}$ appeared also from the composition of the alloy. 


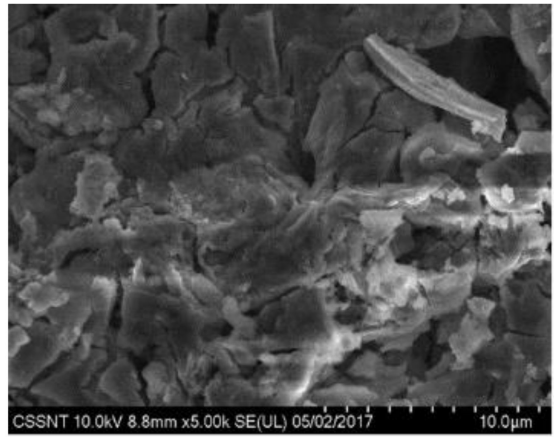

a

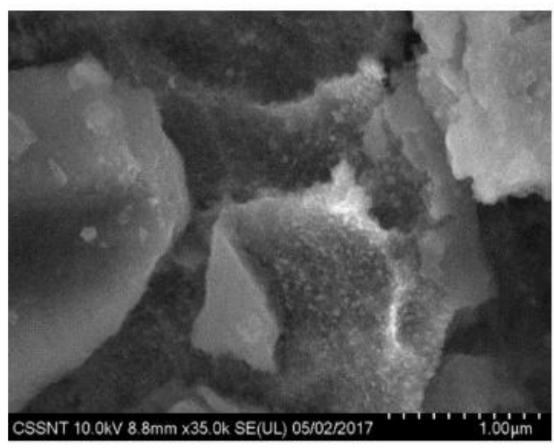

C

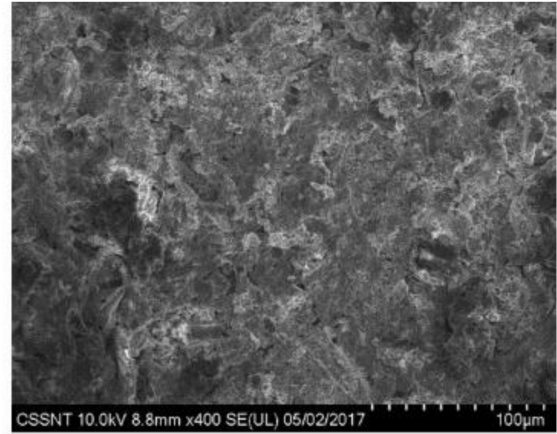

b

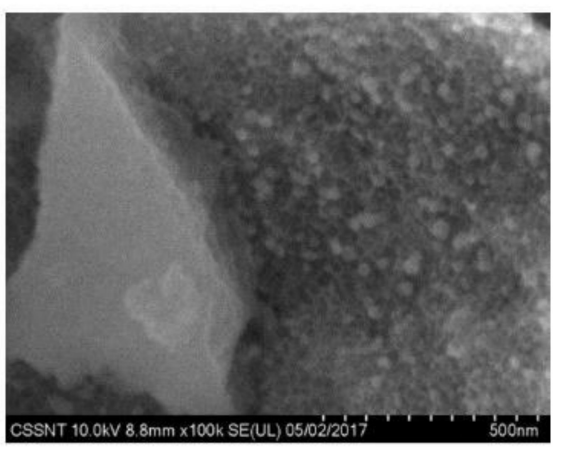

d

Figure 5. The surface morphology for S4 using different magnifications: (a) $400 \times$; (b) $5 \mathrm{k} \times$; (c) $35 \mathrm{k} \times$; (d) $100 \mathrm{k} \times$.

Table 2. Composition expressed in atomic percent at \% (elemental analysis).

\begin{tabular}{ccccccccc}
\hline Sample & $\mathbf{C}$ & $\mathbf{O}$ & $\mathbf{S i}$ & $\mathbf{C r}$ & $\mathbf{C o}$ & $\mathbf{Z r}$ & Nb & Mo \\
\hline S2 & $6.91 \pm 1.15$ & $32.74 \pm 1.11$ & $2.81 \pm 0.04$ & $16.21 \pm 1.11$ & $30.91 \pm 1.19$ & $0.99 \pm 0.11$ & $5.55 \pm 0.55$ & $3.89 \pm 0.23$ \\
\hline S3 & $5.93 \pm 1.10$ & $55.36 \pm 1.24$ & $3.65 \pm 0.03$ & $11.61 \pm 1.09$ & $11.79 \pm 1.11$ & $3.95 \pm 0.25$ & $4.61 \pm 0.34$ & $3.11 \pm 0.15$ \\
\hline S4 & $14.63 \pm 1.12$ & $50.11 \pm 1.13$ & $2.28 \pm 0.02$ & $14.25 \pm 1.05$ & $8.34 \pm 1.15$ & $1.28 \pm 0.12$ & $6.95 \pm 0.45$ & $2.17 \pm 0.25$ \\
\hline
\end{tabular}

From Table 2, after performing the elemental quantitative analysis, we can see that $0 \%$ appeared more than the $32 \%$ that appeared on the surface of the first sample. Some oxides are probably formed on the surface. For the sample oxidized at $1.05 \mathrm{~V}$, more than 55 at \% appeared on the surface of the sample. This is because some oxides are formed on the surface; more experiments using the X-ray diffraction method needed to be completed to establish what species of oxides appeared. For the sample oxidized at $1.1 \mathrm{~V}$, more than 50 at $\%$ of the chemical composition was oxygen, but compared with the second sample, the percentage of oxygen decreased by $5.5 \%$. The slight decrease in the percentage of oxygen recorded in the layer formed on the surface of sample four compared to sample three was due to the detachment of the oxide from the surface and the cracking of this oxide layer.

Figure 6 presents the variation of the oxygen percentages for the anodized samples. 


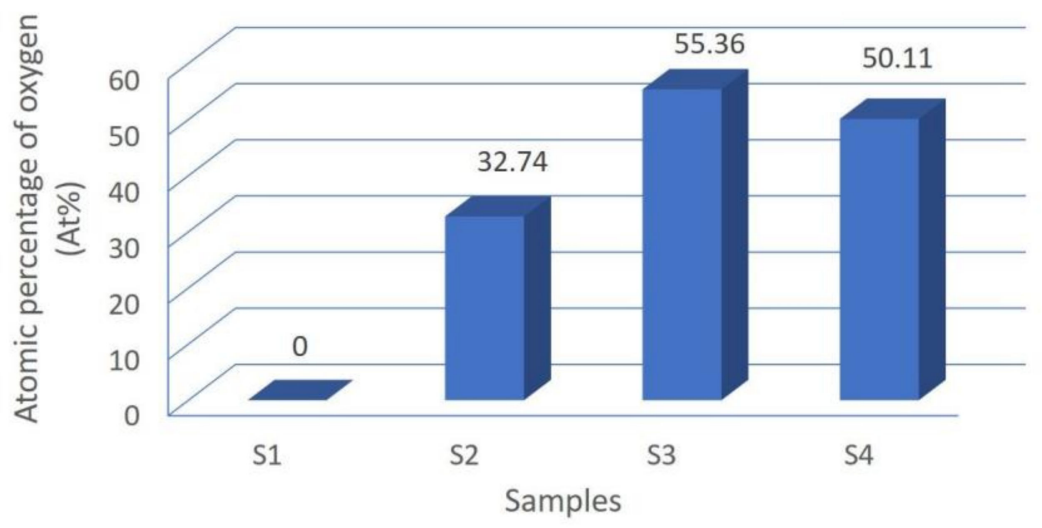

Figure 6. Comparison between the oxygen percentages for all the analyzed samples.

Compared to the untreated $\mathrm{Co}-\mathrm{Cr}$ sample used as a standard, a significant percentage of oxygen appeared for the sample S2. For the other two samples S3 and S4, anodized at $1.05 \mathrm{~V}$, and $1.1 \mathrm{~V}$, respectively, the oxygen content was around 50 at \%.

\subsubsection{XRD Measurements}

The XRD diffractogram presented in Figure 7 shows that the sample was composed of several types of oxides of the constituent elements of the alloy. Thus, $\mathrm{Cr}_{2} \mathrm{O}_{3}, \mathrm{CoO}, \mathrm{NbO}$ but also $\mathrm{MoO}_{3}$ can be observed. The $\mathrm{Cr}_{2} \mathrm{O}_{3}$ pattern shows several diffraction peaks, the most important of which are at $33.6^{\circ}, 36.2^{\circ}, 24.5^{\circ}, 50.2^{\circ}, 2$ theta corresponding to the (104), (110), (012) and (024), planes of the chromium oxide phase. This confirms the formation of the Eskolite phase in the pure $\mathrm{Cr}_{2} \mathrm{O}_{3}$ structure, in which the peaks are attributed to the rhombohedral structure [32]. For $\mathrm{CoO}$, the $34.1^{\circ}$ peaks corresponded to the (111) planes, and peaks at $39.6^{\circ}(200), 57.2^{\circ}(220), 68.3^{\circ}$ (311) can also be observed [33]. The XRD patterns from Figure 7 showed that in addition to the $\mathrm{Cr}_{2} \mathrm{O}_{3}$ and $\mathrm{CoO}$ peaks for the alloy there were more diffraction peaks which confirm the presence of $\mathrm{NbO}$ and $\mathrm{MoO}_{3}$ on the surface of the analyzed samples. Thus, the most important peaks for $\mathrm{NbO}$ at $36.8^{\circ}(111), 42.9^{\circ}$ (200), or $\mathrm{MoO}_{3} 27.3^{\circ}$ (210) and $33.8^{\circ}$ (111) can be noticed [34-36].

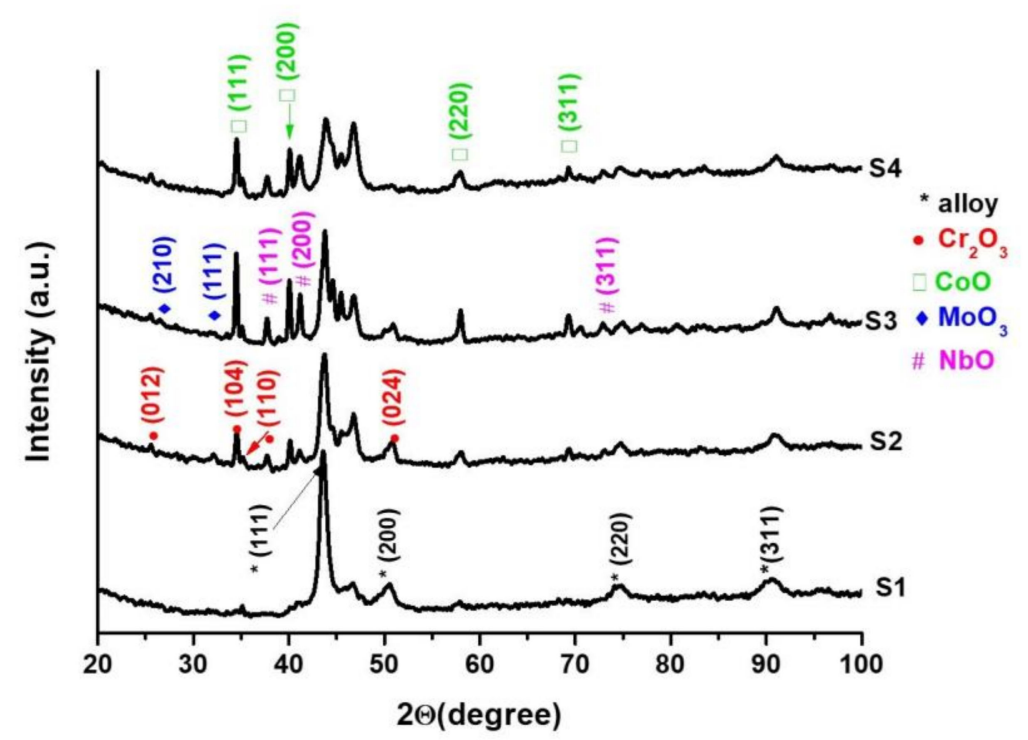

Figure 7. XRD diffractogram of the coated and uncoated CoCrNbMoZr alloy.

\subsection{Contact Angle Evaluation}

For the measurements, we used distilled water as a polar liquid. The contact angle measurements showed that the anodization conferred a hydrophobic character on the 
surfaces for the samples S2 and S4, while the surface of sample S3 became hydrophilic, as can be seen in Figure 8.

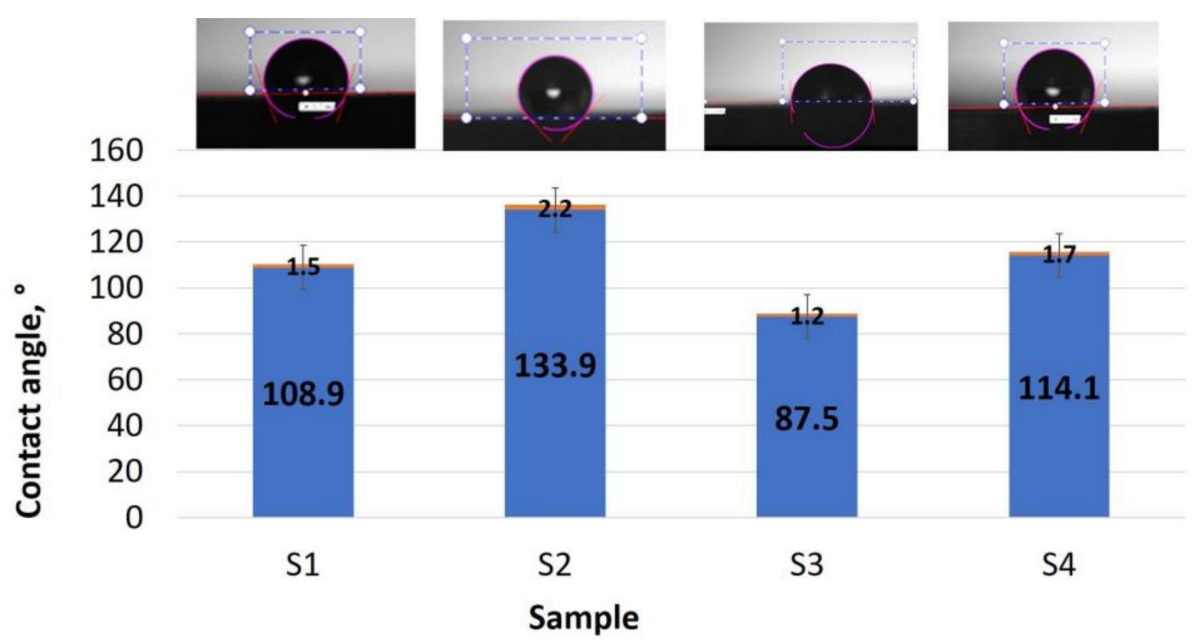

Figure 8. Contact angle values, error bars and the images for all 4 types of the studied samples.

For sample two, after the anodization at $1.00 \mathrm{~V}$, the contact angle increased by $25^{\circ}$. This was due to the formation of a compact oxide layer on the surface, without pores and without cracks, which determined the increase in the hydrophobicity of the sample compared with untreated $\mathrm{Co}-\mathrm{Cr}$.

The anodization of sample three at $1.05 \mathrm{~V}$ led to a wettability increase (showing a small increase in hydrophilic properties), and contact angles of less than 90 degrees that highlight a decrease in the hydrophilic character of the sample, while the anodization at $1.00 \mathrm{~V}$ and $1.10 \mathrm{~V}$ caused an increase in surface hydrophobicity. The decrease in the contact angle in sample three was probably because the surface became porous, and the water droplets were absorbed easily in the oxide layer [36]. The obtained results were also confirmed by the literature, according to which the wettability is influenced by the content of oxygen. As the oxygen content declines, the contact angle usually gradually rises [37]. For sample four, the contact angle value was close to the value of the contact angle for the untreated sample because the oxide film formed on the surface had cracked. The literature shows that molybdenum trioxide $\left(\mathrm{MoO}_{3}\right)$ films act as superhydrophobic support.

\subsection{Electrochemichal Characterisation}

\subsubsection{Open Circuit Potential Tests}

The evolution of open circuit potential (OCP) during $10 \mathrm{~min}$ for both the non-anodized sample and for the three types of anodized samples can be seen in Figure 9. For all the samples studied, we can observe two distinct stages. If in the first stage, i.e. in the first seconds immediately after the immersion in Ericsson artificial saliva, the potential values shift rapidly towards electronegative values, in the second stage the open circuit potential values move very easily to more electronegative values, so that a plateau is reached very quickly. This plateau is obtained because in an extremely short time it reaches a stable state due to the formation of a mixture of oxides on the surface of the anodized samples, as previously established from the EDX and XRD analyzes [18]. The composition of the surface passive film formed on the traditionally elaborated CoCrMo alloy immersed in a simulated physiological solution was investigated many years ago, and it was established that $\mathrm{CoCrMo}$ alloys have a dendritic microstructure surface with a 1 to $4 \mathrm{~nm}$ thick stable oxide layer. It is mainly $\mathrm{Cr}_{2} \mathrm{O}_{3}$ that constitutes a biological corrosion barrier opposing the oral environment [38]. 


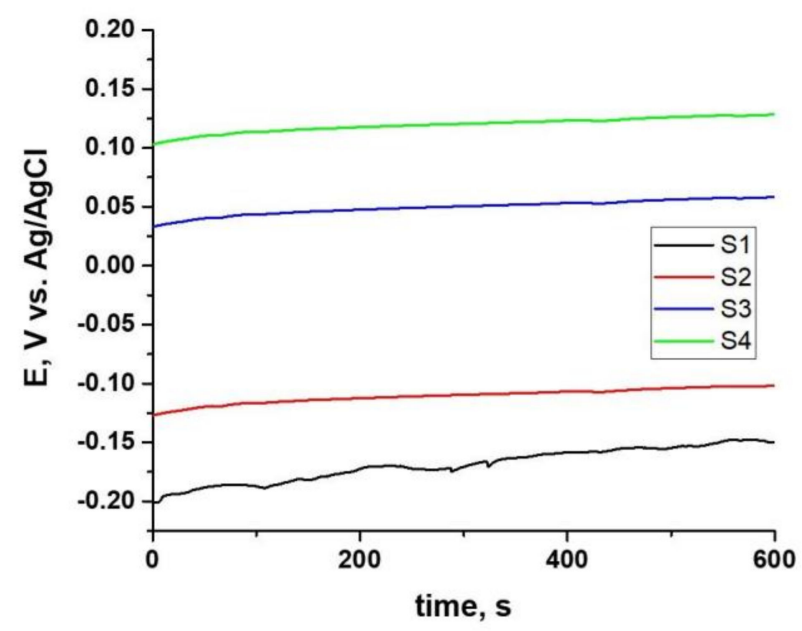

Figure 9. Open circuit potential behavior in Ericsson artificial saliva at $37^{\circ} \mathrm{C}$ for the coated and uncoated CoCrNbMoZr alloy.

According to previous results, initially the new alloy, having only native oxide, is included in the conventional stability scale as "Perfect Stable" $[39,40]$. The non-oxidized alloy reached its stable passive state after a longer time period than the treated alloy, its passivation process having a lower passivation rate. This slower growth rate of the passivating films can be observed in Figure 9 but the open circuit potentials tended to more electropositive values, indicating an increase in the passive film thickness.

In the case of non-anodized alloys, small variations in the potential value were observed, but in the end it stabilized. It was also noticed that the value at which the potential for the untreated alloy stabilized was the most electronegative.

As can be observed from Figure 9, the most electropositive values of the potential were reached by the anodized sample at a potential of $1.1 \mathrm{~V}$, i.e., the $\mathrm{S} 4$ sample.

\subsubsection{Electrochemical Impedance Spectroscopy Measurements}

Another electrochemical method used to characterize both the non-anodized alloy and the three types of the anodized alloy samples was electrochemical impedance spectroscopy. The spectra recorded at potential in open circuit after $10 \mathrm{~min}$ of immersion in artificial saliva are presented as Nyquist and Bode diagrams in Figure 10. As we can see from the Nyquist diagrams (Figure 10a), a single open capacitive appeared for all four types of the samples studied. For all the anodized samples, higher values of the capacitive semicircle diameter were recorded compared to the non-anodized alloy. This indicates an increase in the polarization resistance of the anodized alloys and, finally, a decrease in the corrosion rate of these samples in the studied artificial saliva. Corresponding to this capacitive semicircle, on the Bode diagram (Figure 10b) one can observe a single maximum of the phase angle value, so one single time constant. As we can observe, the maximum phase angle moves very slowly towards lower frequencies for the values for all the anodized samples if we compare them with the values for the non-anodized alloy. This increase in the maximum phase angle values from $-47^{\circ}$ to $-68^{\circ}$ indicates that all three types of the anodized samples studied managed to protect the alloy in the artificial saliva of the Ericsson type. 


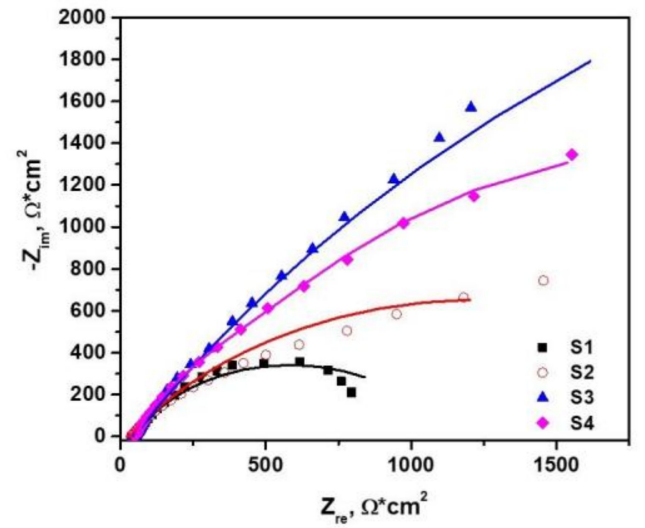

a

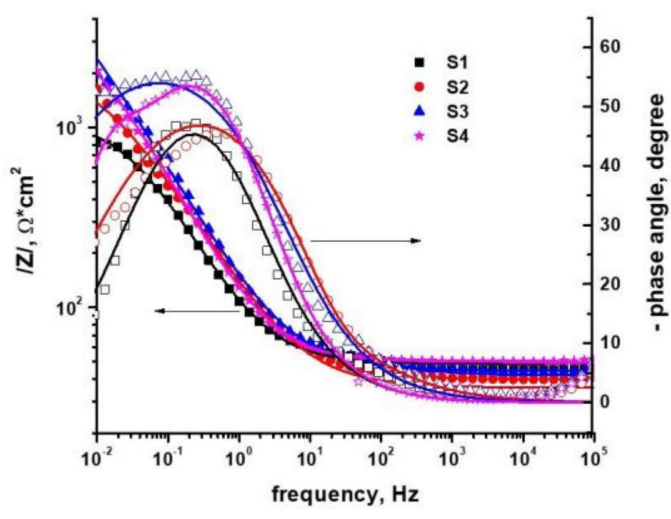

b

Figure 10. Nyquist (a) and Bode (b) diagrams for the coated and uncoated CoCrNbMoZr alloys immersed in Ericsson artificial saliva. The symbols show experimental data, whereas the lines represent fitted data using the electrical equivalent circuit (EEC).

Using ZView software (Scribner Associates Inc., Southern Pines, NC, USA) and the electrical equivalent circuit (EEC) presented in Figure 11, the experimental impedance data were modelled. The obtained values of the equivalent electrical circuit elements are presented in Table 3. A value of Chi-quadrate $\left(\chi^{2}\right)$ of approximately $10^{-2}$ was found when the experimental data were fitted, so it can be said that the fitting errors were small. Figure 10 shows, in all cases, that the correlation between the experimental data and the simulated data was very strong.

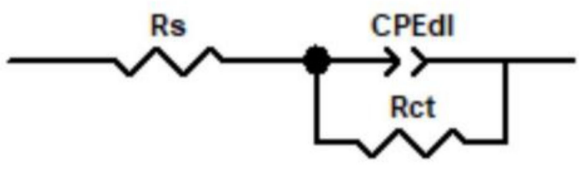

a

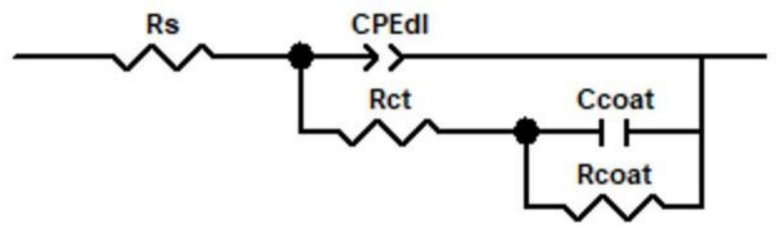

b

Figure 11. Models for the equivalent electrical circuit proposed for fitting the experimental impedance spectra, (a) for non-anodized alloy and (b) for anodized samples.

Table 3. The values of the equivalent electrical circuit elements for the uncoated and coated CoCrNbMoZr alloys immersed in Ericsson artificial saliva at $37^{\circ} \mathrm{C}$.

\begin{tabular}{|c|c|c|c|c|c|c|c|}
\hline Sample & $\begin{array}{c}\text { Rs, } \\
\Omega \cdot \mathrm{cm}^{2}\end{array}$ & $\begin{array}{l}\text { CPEdl-T, } \\
\text { F. } \mathrm{cm}^{-2}\end{array}$ & CPEdl-P & $\begin{array}{c}\text { Rct, } \\
\Omega \cdot \mathrm{cm}^{2}\end{array}$ & $\begin{array}{l}\text { Ccoat, } \\
\mathrm{F} \cdot \mathrm{cm}^{-2}\end{array}$ & $\begin{array}{l}\text { Rcoat, } \\
\Omega \cdot \mathrm{cm}^{2}\end{array}$ & $\begin{array}{c}\text { Chi-Squared } \\
\left(\chi^{2}\right)\end{array}$ \\
\hline S1 & 48.72 & $3.27 \times 10^{-6}$ & 0.72 & 1071 & - & - & $1.3 \times 10^{-3}$ \\
\hline S2 & 35.6 & $2.41 \times 10^{-6}$ & 0.68 & 35.3 & $1.15 \times 10^{-5}$ & 2400 & $1.2 \times 10^{-2}$ \\
\hline S3 & 43.1 & $1.09 \times 10^{-6}$ & 0.71 & 50.6 & $3.52 \times 10^{-5}$ & 20696 & $1 \times 10^{-2}$ \\
\hline S4 & 49.9 & $2.21 \times 10^{-6}$ & 0.69 & 37.3 & $4.34 \times 10^{-5}$ & 5245 & $5.6 \times 10^{-3}$ \\
\hline
\end{tabular}

For the non-anodized alloy, the model proposed in Figure 11a was used, which is a simple Randles circuit, consisting of the resistance of the electrolyte between the working and the reference electrode (Rs) and a parallel combination of the double layer capacitance, CPEdl. A charge transfer resistance, Rct, was added to the equivalent circuit to characterise the electrolyte-substrate interface. The charge transfer resistance (Rf) is related to the rate of corrosion reactions [41]. In the case of the anodized samples, the model in Figure 11b was used. Specifically, the proposed model for the non-anodized sample was completed 
with the coating capacitance (CPEcoat) and the resistance associated to the coating (Rcoat). As we can see, at high frequencies, the absolute impedance curve is almost independent of the frequency, with a phase angle of $0^{\circ}$, representing the electrolyte resistance. The resistance values of the solution remained relatively constant in the four cases studied.

The obtained fitting parameters presented in Table 3 reveal high values of the coating resistance Rf, and low values of capacitance component of $\mathrm{CPE}$, values that prove the high capacitive behavior of the coatings. The CPE-P independent parameter presents values close to 1 , evincing the ideal capacitors for the studied samples. The highest $\mathrm{Rf}$ value was obtained for the $\mathrm{S} 3$ sample, anodized at $1.05 \mathrm{~V}$, indicating the best anti-corrosion coating in Ericsson artificial saliva.

\subsubsection{Potentiodynamic Tests}

Potentiodynamic tests performed in Ericsson artificial saliva led to the recording of the polarization curves shown in Figure 12. The applied potential varied from -300 to $+1100 \mathrm{mV}$ vs. open circuit potential to surpass the potential of $+300 \mathrm{mV}$, which is comparable to the potential measured inside the oral cavity [42]. The anodic polarization curve of the unoxidized sample (S1) showed a typical passivation zone. As can be seen for all three types of the anodized samples, lower corrosion current density values were obtained than for the non-anodized alloy. In addition, a shift of the corrosion potential towards electropositive values for the coated samples can be observed from Figure 12. As the coated samples have more positive corrosion potential, it can be inferred that the coating was less susceptible to undergo corrosion in Ericsson artificial saliva.

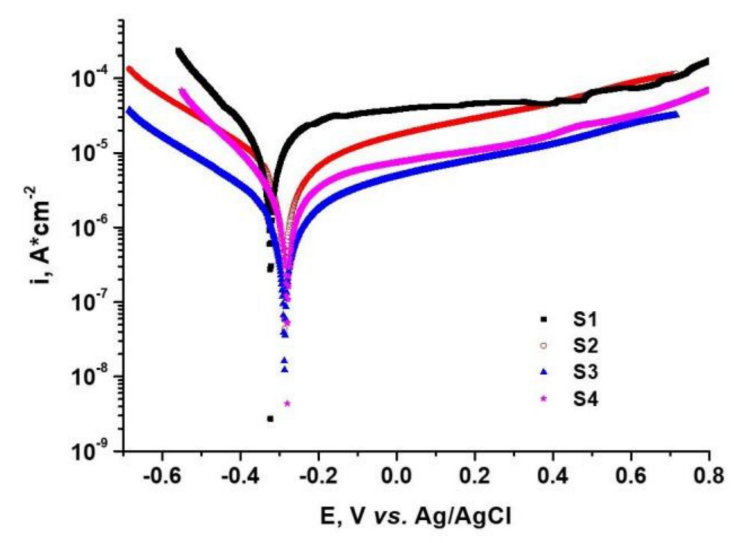

Figure 12. Polarization curves for the coated and uncoated $\mathrm{CoCrNbMoZr}$ alloys in Ericsson artificial saliva at $37^{\circ} \mathrm{C}$.

Tafel slopes extrapolation and polarization resistance methods were used to calculate the corrosion kinetic parameters obtained from the polarization curves shown in Figure 12. The values obtained for the corrosion potential ( $\left.\mathrm{E}_{\text {corr }}\right)$, corrosion current density ( $\left.\mathrm{i}_{\text {corr }}\right)$ and polarization resistance $\left(R_{P}\right)$ are shown in Table 4 .

Table 4. Kinetic corrosion parameters of the studied alloy in artificial saliva.

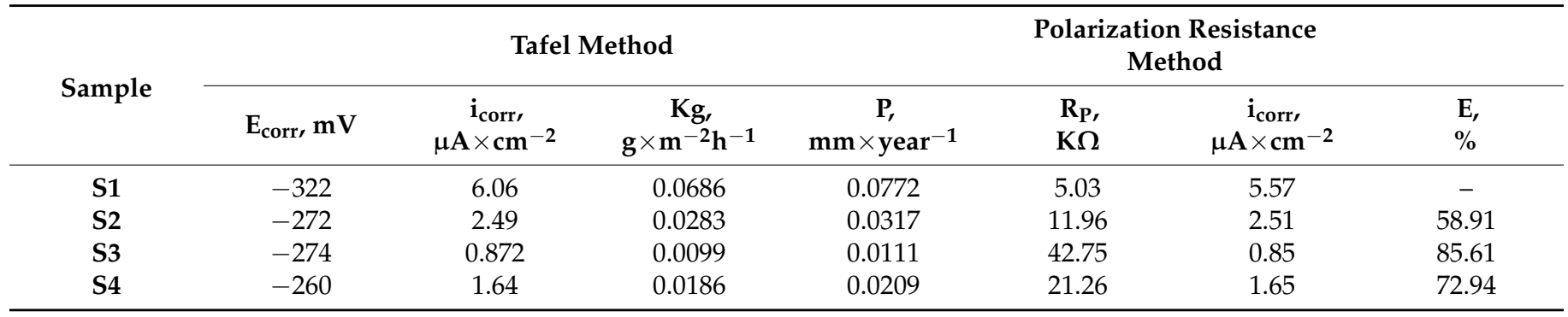


The shift of $\mathrm{E}_{\text {corr }}$ values in a positive direction suggested that the material became nobler due to the passive layer formed on its surface.

As can be seen, similar values were obtained for the corrosion current density using the two methods. For all three types of the anodized samples, lower values of the corrosion current density were obtained compared to the non-anodized alloy. The lowest value for the corrosion current density was obtained for sample S3, anodized at 1.05 V. Moreover, in the case of the anodized alloys, higher polarization resistance values were obtained than for the untreated alloys, indicating a decrease in the corrosion rate in Ericsson artificial saliva for all three types of the coated alloys.

It can be said that the formation of oxides by anodizing on the surface of the $\mathrm{CoCr}$ alloy leads to the improvement of the anticorrosive properties of the samples. The presence of chromium in the alloy leads to the formation of a passive $\mathrm{Cr}_{2} \mathrm{O}_{3}$ film on the alloy surface. Moreover, a higher content of $\mathrm{Cr}_{2} \mathrm{O}_{3}$ and $\mathrm{MoO}_{3}$ in the passive film leads to a significant resistance to metal ion transfer through the passive film.

Based on the kinetic parameters presented in Table 4, the protective coating efficiency could also be calculated, E (\%). This was determined according to Equation (1).

$$
P_{i}(\%)=\left[1-\left(\frac{i_{\text {corr }}}{i_{\text {corr }}^{0}}\right)\right] \times 100
$$

where: $i_{c o r r}$ and $i_{c o r r}^{0}$ are the corrosion current densities of the coating and the substrate, respectively.

The best efficiency in the protection of the $\mathrm{Co}-\mathrm{Cr}$ alloy in Ericsson artificial saliva was obtained for the anodized sample at $1.05 \mathrm{~V}$.

\section{Conclusions}

A coating on a new $\mathrm{CoCrNbMoZr}$ dental alloy using an anodic oxidation procedure was discussed in this paper. A comparison between a non-anodized and three anodized samples of the same alloy at three potentials of $1 \mathrm{~V}, 1.05 \mathrm{~V}$ and $1.1 \mathrm{~V}$ was made. We demonstrated that the anodization procedure is an easy and cheap way to obtain surfaces with superior anti-corrosion properties.

From SEM determinations we established the morphology of the samples and from XRD analysis, an oxides phase was identified.

For all three samples, from anodized alloys, the percentage of oxygen that appeared in the EDX spectrum was greater than 32 at.\%.

The presence of $\mathrm{Cr}_{2} \mathrm{O}_{3}$ and $\mathrm{MoO}_{3}$ in the passive film led to a significant resistance to metal ion transfer through the passive film. The contact angle showed that the anodization conferred a decrease of hydrophilic character of the sample anodized at $1.05 \mathrm{~V}$, while the anodization at $1 \mathrm{~V}$ and $1.1 \mathrm{~V}$ causes an increase in surface hydrophobicity.

From the electrochemical studies we observed that all three types of anodizing studied protected the alloy from corrosion in Ericsson artificial saliva. For all three types of the anodized samples, lower values of the corrosion current density were obtained compared to the non-anodized alloy. The best anti-corrosion properties were obtained for the S3 sample, anodized at $1.05 \mathrm{~V}$. The corrosion resistance as a function of the potential of anodization is a result of the combined effect of various surface features. The high corrosion resistance of oxidized samples in Ericsson saliva was revealed in the experimentally quantified results of electrochemical measurements and was due to the presence of a mixture of all the oxides identified in the XRD experiments $\left(\mathrm{Cr}_{2} \mathrm{O}_{3}, \mathrm{MoO}_{3}, \mathrm{CoO}, \mathrm{NbO}\right)$.

Author Contributions: Conceptualization, F.G.I., F.G. and I.D.; methodology, F.G.I.; software, M.P.; validation, M.P., F.G. and I.D.; formal analysis, F.G.I. and M.P; investigation, F.G.I.; data curation, M.P and F.G; writing —original draft preparation, F.G. and M.P.; writing—review and editing, F.G. and I.D.; visualization, M.P and F.G.; supervision, I.D. All authors have read and agreed to the published version of the manuscript.

Funding: This research received no external funding. 
Data Availability Statement: The data presented in this study are available upon request.

Conflicts of Interest: The authors declare no conflict of interest.

\section{References}

1. Ambili, C.; Keshava Prasad, B.S. The era of future dentistry: Recent advances and future perspectives of restorative dentistry: A literature review. Int. J. Appl. Dent. Sci. 2019, 5, 111-116.

2. Dawood, A.; Marti, B.M.; Sauret-Jackson, V.; Darwood, A. 3D printing in dentistry. Br. Dent. J. 2015, 219, 521-529. [CrossRef]

3. Padrós, R.; Punset, M.; Molmeneu, M.; Brizuela Velasco, A.; Herrero-Climent, M.; Rupérez, E.; Gil, F.J. Mechanical Properties of CoCr Dental-Prosthesis Restorations Made by Three Manufacturing Processes. Influence of the Microstructure and Topography. Metals 2020, 10, 788. [CrossRef]

4. Scharf, B.; Clement, C.C.; Zolla, V.; Perino, G.; Yan, B.; Elci, S.G.; Purdue, E.; Goldring, S.R.; Macaluso, F.; Cobelli, N.; et al. Molecular analysis of chromium and cobalt-related toxicity. Sci. Rep. 2015, 4, 5729. [CrossRef] [PubMed]

5. Duarte, I.; Amorim, J.R.; Perázzio, E.F.; Schmitz Junior, R. Metal contact dermatitis: Prevalence to nickel, cobalt and chromium. An. Bras. Dermatol. 2005, 80, 137-142. [CrossRef]

6. Golgovici, F.; Prodana, M.; Ionascu, F.G.; Demetrescu, I. A Comparative Electrochemical and Morphological Investigation on the Behavior of $\mathrm{NiCr}$ and $\mathrm{CoCr}$ Dental Alloys at Various Temperatures. Metals 2021, 11, 256. [CrossRef]

7. Lugovic-Mihic, L.; Ilić, I.; Budimir, J.; Pondeljak, N.; Mravak Stipetić, M. Common allergies and allergens in oral and perioral diseases. Acta Clin. Croat. 2020, 59, 318-328. [CrossRef] [PubMed]

8. Chen, P.; Liu, H.; Niinomi, M.; Horita, Z.; Fujii, H.; Hanawa, T. Fatigue property and cyto compatibility of a biomedical Co-Cr-Mo alloy subjected to a high-pressure torsion and a subsequent short time annealing. Mater. Trans. 2020, 61, 361-367. [CrossRef]

9. Ramírez-Ledesma, L.; Roncagliolo, P.; Alvarez-Perez, M.A.; Lopez, H.F.; Juárez-Islas, J.A. Corrosion assessment of an implantable dental Co-Cr alloy in artificial saliva and biocompatibility behavior. J. Mater. Eng. Perform. 2020, 29, 1657-1670. [CrossRef]

10. Galateanu, B.; Golgovici, F.; Hudita, A.; Stan, M.; Dinescu, S.; Costache, M.; Demetrescu, I.; Popescu, A. About electrochemical stability and biocompatibility of two types of CoCr commercial dental alloys. Mater. Corros. 2016, 67, 1096-1104. [CrossRef]

11. Liu, R.; Li, X.; Hu, X.; Dong, H. Surface modification of a medical grade Co-Cr-Mo alloy by low-temperature plasma surface alloying with nitrogen. Surf. Coat. Techn. 2013, 232, 906-911. [CrossRef]

12. Romonti, D.C.; Iskra, J.; Bele, M.; Demetrescu, I.; Milošev, I. Elaboration and characterization of fluorohydroxyapatite and fluoroapatite sol- gel coatings on CoCrMo alloy. J. Alloys Compd. 2016, 665, 355-364. [CrossRef]

13. Ahirwar, H.; Zhou, Y.; Mahapatra, C.; Ramakrishna, S.; Kumar, P.; Nanda, H.S. Materials for Orthopedic Bioimplants: Modulating Degradation and Surface Modification Using Integrated Nanomaterials. Coatings 2020, 10, 264. [CrossRef]

14. Golgovici, F.; Prodana, M.; Popescu, A. Effect of reprocessing treatment on the corrosion of Co-Cr alloy in acid media. Rev. Chim. 2015, 66, 660-667.

15. Ionita, D.; Man, I.; Demetrescu, I. The behaviour of electrochemical deposition of phosphate coating on CoCr bio alloys. Key Eng. Mater. 2007, 330-332, 545-548. [CrossRef]

16. Mezour, M.A.; Oweis, Y.; El-Hadad, A.A.; Algizani, S.; Tamimi, F.; Cerruti, M. Surface modification of CoCr alloys by electrochemical reduction of diazonium salts. RSC Adv. 2018, 8, 23191-23198. [CrossRef]

17. Zhang, E. A new antibacterial Co-Cr-Mo-Cu alloy: Preparation, biocorrosion, mechanical and antibacterial property. Mat. Sci. Eng. C 2016, 69, 134-143. [CrossRef] [PubMed]

18. Drob, S.I.; Vasilescu, C.; Andrei, M.; Calderon Moreno, J.M.; I Demetrescu, I. Microstructural, mechanical and anticorrosion characterisation of new CoCrNbMoZr alloy. Mater. Corros. 2015, 67, 739-747. [CrossRef]

19. Zhang, E.; Zhao, X.; Hu, J.; Wang, R.; Fu, S.; Qin, G. Antibacterial metals and alloys for potential biomedical implants. Bioact. Mater. 2021, 6, 2569-2612. [CrossRef] [PubMed]

20. Matusiewicz, H. Potential release of in vivo trace metals from metallic medical implants in the human body. From ions to nanoparticles - a systematic analytical review. Acta Biomater. 2014, 10, 2379-2403. [CrossRef] [PubMed]

21. Laine, J.; Kalimo, K.; Happonen, R.P. Contact allergy to dental restorative materials in patients with oral lichenoid lesions. Contact Dermat. 1997, 36, 141-146. [CrossRef]

22. Regulation (EU) $2017 / 745$ of the European Parliament and of the Council of 5 April 2017 on Medical Devices. Available online: http:/ / data.europa.eu/eli/reg/2017/745/ (accessed on 15 May 2021).

23. Vaicelyte, A.; Janssen, C.; Le Borgne, M.; Grosgogeat, B. Cobalt-Chromium Dental Alloys: Metal Exposures, Toxicological Risks, CMR Classification, and EU Regulatory Framework. Crystals 2020, 10, 1151. [CrossRef]

24. Han, W.; Fang, F. Investigation of electrochemical properties of electropolishing Co-Cr dental alloy. J. Appl. Electrochem. 2020, 50, 367-381. [CrossRef]

25. Andrei, M.; Galateanu, B.; Hudita, A.; Costache, M.; Osiceanu, P.; Moreno, J.M.C.; Demetrescu, I. Electrochemical comparison and biological performance of a new CoCrNbMoZr alloy with commercial CoCrMo alloy. Mater. Sci. Eng. C 2016, 59, 346-355. [CrossRef]

26. Ionita, D.; Golgovici, F.; Mazare, A.; Badulescu, M.; Demetrescu, I. Corrosion and antibacterial characterization of Ag-DLC coatingon a new CoCrNbMoZr dental alloy. Mater. Corros. 2018, 69, 1403-1411. [CrossRef]

27. Kozbial, A.; Li, Z.; Conaway, C.; McGinley, R.; Dhingra, S.; Vahdat, V.; Zhou, F.; D’Urso, B.; Liu, H.; Li, L. Study on the surface energy of graphene by contact angle measurements. Langmuir 2014, 30, 8598-8606. [CrossRef] [PubMed] 
28. Katsikogianni, M.; Missirlis, Y.F. Concise review of mechanisms of bacterial adhesion to biomaterials and of techniques used in estimating bacteria-material interactions. Eur. Cell. Mater. 2004, 8, 37-57. [CrossRef]

29. Duffó, G.S.; Quezada Castillo, E. Development of an Artificial Saliva Solution for Studying the Corrosion Behavior of Dental Alloys. Corrosion 2004, 60, 594-602. [CrossRef]

30. Al-Imam, H.; Benetti, A.R.; Ozhayat, E.B.; Pedersen, A.M.L.; Johansen, J.D.; Thyssen, J.; Jellesen, M.S.; Gotfredsen, K. Cobalt release and complications resulting from the use of dental prostheses. Contact Dermat. 2016, 75, 377-383. [CrossRef]

31. Garcia-Falcon, C.M.; Gil-Lopez, T.; Verdu-Vazquez, A.; Mirza-Rosca, J.C. Electrochemical characterization of some cobalt base alloys in Ringer solution. Mat. Chem. Phys. 2021, 260, 124164. [CrossRef]

32. Tsegay, M.G.; Gebretinsae, H.G.; Nuru, Z.Y. Structural and optical properties of green synthesized $\mathrm{Cr}_{2} \mathrm{O}_{3}$ nanoparticle. Mater. Today Proc. 2021, 36, 587-590. [CrossRef]

33. Guo, Q.; Guo, X.; Tian, Q. Optionally ultra-fast synthesis of $\mathrm{CoO} / \mathrm{Co}_{3} \mathrm{O}_{4}$ particles using $\mathrm{CoCl}_{2}$ solution via a versatile spray roasting method. Adv. Powder Technol. 2010, 21, 529-533. [CrossRef]

34. Li, J.; Liu, W.W.; Zhou, H.M.; Liu, Z.Z.; Chen, B.R.; Sun, W.J. Anode material NbO for Li-ion battery and its electrochemical properties. Rare Met. 2018, 37, 118-122. [CrossRef]

35. Wu, D.; Shen, R.; Yang, R.; Ji, W.; Jiang, M.; Ding, W.; Peng, L. Mixed Molybdenum Oxides with Superior Performances as an Advanced Anode Material for Lithium-Ion Batteries. Sci. Rep. 2017, 7, 44697. [CrossRef] [PubMed]

36. Benedetti, T.; Gonçales, V.; Petri, D.; Córdoba de Torresi, S.; Torresi, R. Macroporous $\mathrm{MnO}_{2}$ electrodes obtained by template assisted electrodeposition for electrochemical capacitors. J. Braz. Chem. Soc. 2010, 21, 1704-1709. [CrossRef]

37. Zhou, G.; Xu, C.; Cheng, W.; Zhang, Q.; Nie, W. Effects of Oxygen Element and Oxygen-Containing Functional Groups on Surface Wettability of Coal Dust with Various Metamorphic Degrees Based on XPS Experiment. J. Anal. Methods Chem. 2015, 2015 , 467242. [CrossRef]

38. Milosev, I.; Strehblow, H.H. The composition of the surface passive film formed on CoCrMo alloy in simulated physiological solution. Electrochim. Acta 2003, 48, 2767-2774. [CrossRef]

39. Vasilescu, E.; Drob, P.; Raducanu, D.; Cinca, E.; Mareci, D.; Calderon Moreno, J.M.; Popa, M.; Vasilescu, C.; Mirza Rosca, J.C. Effect of thermo-mechanical processing on the corrosion resistance of Ti6Al4V alloys in biofluids. Corros. Sci. 2009, 51, 2885-2896. [CrossRef]

40. ISO 8044/2000. Corrosion of metals and alloys. Basic terms and definitions Status: Revised, Withdrawn Published: April 2000 Replaced By: BS EN ISO8044:2020.

41. Valero Vidal, C.; Igual Muñoz, A. Electrochemical characterisation of biomedical alloys for surgical implants in simulated body fluids. Corros. Sci. 2008, 50, 1954-1961. [CrossRef]

42. Yang, L.; Zhu, Q.; Xie, X.; Cao, X.; Wu, Y.; Chen, S.; Qu, J. Electrochemical behavior of CoCrMo alloy for dental applications in acidic artificial saliva containing albumin. Colloids Surf. B Biointerfaces 2019, 184, 110492. [CrossRef] 